\title{
Mechanisms of Glucose Hypersensitivity in $\beta$-Cells From Normoglycemic, Partially Pancreatectomized Mice
}

\author{
Franz Martín, Etelvina Andreu, Juan Manuel Rovira, Jose A.G. Pertusa, Mercé Raurell, Cristina Ripoll, \\ Juan Vicente Sanchez-Andrés, Eduard Montanya, and Bernat Soria
}

\begin{abstract}
Increased $\beta$-cell sensitivity to glucose precedes the loss of glucose-induced insulin secretion in diabetic animals. Changes at the level of $\beta$-cell glucose sensor have been described in these situations, but it is not clear whether they fully account for the increased insulin secretion. Using a euglycemic-normolipidemic $60 \%$ pancreatectomized (60\%-Px) mouse model, we have studied the ionic mechanisms responsible for increased $\beta$-cell glucose sensitivity. Two weeks after Px (Px14 group), Px mice maintained normoglycemia with a reduced $\beta$-cell mass ( $0.88 \pm 0.18 \mathrm{mg})$ compared with control mice $(1.41 \pm 0.21 \mathrm{mg})$. At this stage, the dose-response curve for glucose-induced insulin release showed a significant displacement to the left $(P<0.001)$. Islets from the Px14 group showed oscillatory electrical activity and cytosolic $\mathrm{Ca}^{2+}\left(\left[\mathrm{Ca}^{2+}\right]_{i}\right)$ oscillations in response to glucose concentrations of $5.6 \mathrm{mmol} / \mathrm{l}$ compared with islets from the control group at $11.1 \mathrm{mmol} / \mathrm{l}$. All the above changes were fully reversible both in vitro (after 48-h culture of islets from the Px14 group) and in vivo (after regeneration of $\beta$-cell mass in islets studied 60 days after $P x)$. No significant differences in the input resistance and ATP inhibition of ATP-sensitive $\mathrm{K}^{+}\left(\mathrm{K}_{\mathrm{ATP}}\right)$ channels were found between $\beta$-cells from the Px14 and control groups. The dose-response curve for glucoseinduced MTT $\left(\mathrm{C}, N\right.$-diphenyl-N" ${ }^{\prime \prime}-4,5$-dimethyl thiazol 2 yl tetrazolium bromide) reduction showed a significant displacement to the left in islets from the Px14 group $(P<0.001)$. These results indicate that increased glucose sensitivity in terms of insulin secretion and $\mathrm{Ca}^{2+}$ signaling was not due to intrinsic modifications of $K_{\text {ATP }}$ channel properties, and suggest that the changes are most likely to be found in the glucose metabolism. Diabetes 48:1954-1961, 1999
\end{abstract}

From the Institute of Bioengineering and Department of Science and Technology (F.M., E.A.) and the Institute of Bioengineering and Department of Physiology (J.M.R., J.A.G.P., C.R., J.V.S.-A., B.S.), School of Medicine, University Miguel Hernandez, Campus de San Juan, San Juan de Alicante, Alicante; and the Laboratory of Diabetes and Experimental Endocrinology (M.R., E.M.), Endocrine Unit (13-2), CSUB-Hospital of Bellvitge, University of Barcelona, L'Hospitalet de Llobregat, Barcelona, Spain.

Address correspondence and reprint requests to Prof. Bernat Soria, Institute of Bioengineering and Department of Physiology, School of Medicine, Campus de San Juan, U.M.H. San Juan de Alicante, E-03550 Alicante, Spain. E-mail: bernat.soria@umh.es.

Received for publication 30 March 1998 and accepted in revised form 11 June 1999

$\mathrm{AM}$, acetoxymethyl derivative; $\left[\mathrm{Ca}^{2+}\right]_{i}$, cytosolic $\mathrm{Ca}^{2+} ; \mathrm{FFA}$, free fatty acid; IPGTT, intraperitoneal glucose tolerance test; $\mathrm{K}_{\mathrm{ATP}}$, ATP-sensitive $\mathrm{K}^{+} ; \mathrm{KRBB}$ Krebs-Ringer bicarbonate buffer; MTT, C, $N$-diphenyl- $\mathrm{N}^{\prime \prime}-4,5$-dimethyl thiazol 2 yl tetrazolium bromide; Px, pancreatectomy; RIA, radioimmunoassay.

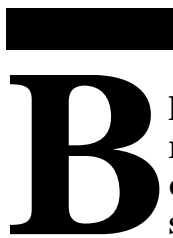

lood glucose level is maintained within a narrow range through a mechanism coupling changes in extracellular glucose concentrations to insulin secretion $(1,2)$. With hyperglycemia, increased glucose metabolism raises the ATP/ADP ratio, which closes ATP-sensitive $\mathrm{K}^{+}\left(\mathrm{K}_{\mathrm{ATP}}\right)$ channels (3); the subsequent depolarization causes bursts of electrical activity (4), cytosolic $\mathrm{Ca}^{2+}\left(\left[\mathrm{Ca}^{2+}\right]_{\mathrm{i}}\right)$ oscillations (5), and insulin release (6). Chronic hyperglycemia, however, results in impaired glucose-induced insulin secretion, a defect that has been considered to play a major role in the pathogenesis of type 2 diabetes (7). Recently, it has been shown that a raised sensitivity to glucose precedes the loss of glucose-induced insulin secretion in hyperglycemic rats (8). However, hyperglycemia did not appear to be the cause of the heightened $\beta$-cell sensitivity to glucose that has also been described in different normoglycemic conditions such as partial pancreatectomy (8), insulin resistance (9), glucose infusion (10), or normal pregnancy (11). A common feature of these normoglycemic conditions with enhanced glucose-stimulated insulin secretion is the increased workload placed on $\beta$-cells, suggesting that the rise in glucose sensitivity represents an adaptive response of the $\beta$-cells to an increased demand for insulin. Changes at the level of the $\beta$-cell glucose sensor, the glucose-phosphorylating enzymes glucokinase and hexokinase $(12,13)$, and the $\beta$-cell glucose transporter GLUT2 (14) have been described in situations of $\beta$-cell hyperfunction. It is not clear, however, whether these changes fully account for the increased insulin secretion.

We recently reported an increased glucose sensitivity in transplanted islets when normoglycemia was restored in diabetic recipients through the transplantation of a limited $\beta$-cell mass. In this model, increased sensitivity was attributed to a resting decrease in the fraction of blockable $\mathrm{K}_{\mathrm{ATP}}$ channels in transplanted $\beta$-cells (15). However, these mice were hyperglycemic for 1 week after transplantation, and therefore the influence of previous hyperglycemia on changes in glucose sensitivity could not be completely ruled out. The aim of the present study was to determine the ionic mechanisms responsible for $\beta$-cell increased glucose sensitivity. The $60 \%$ pancreatectomy (Px) model was chosen because it is known that after $60 \% \mathrm{Px}$, normoglycemia is maintained despite the reduced $\beta$-cell mass, thus excluding the effects of hyperglycemia (8). 


\section{RESEARCH DESIGN AND METHODS}

Partial pancreatectomy model. 60\% Px was performed on 8- to 12-week-old male C57B1/6 mice (B\&K Universal, North Humberside, U.K.) using the method described previously in rats (16). After an overnight fast, mice were anesthetized by intraperitoneal injection of $50 \mathrm{mg} / \mathrm{kg}$ barbital sodium (Normon Laboratory, Madrid), $90 \mathrm{mg} / \mathrm{kg}$ ketamine (Parke-Davis S.L., Barcelona), $0.8 \mathrm{mg} / \mathrm{kg}$ atropine (Braun Medical S.A., Jaen, Spain), and $4 \mathrm{mg} / \mathrm{kg}$ diazepam (Roche S.A., Madrid). After midline abdominal incision, the splenic lobe of the pancreas was mobilized by partially breaking the mesenteric connections to the stomach, small bowel, and retroperitoneum. Pancreatic tissue was removed by gentle abrasion with cotton applicators, with care being taken to leave major blood vessels intact. The excised portion included the splenic lobe of the pancreas but not the small flap attached to the pylorus. To establish the $60 \% \mathrm{Px}$ in mice, in a set of preliminary experiments the pancreatic remnant was excised and weighed immediately after the partial pancreatectomy. The weight was compared with that of normal pancreas of contro (nonpancreatectomized) mice of similar age and weight. The extent of pancreatectomy was modified until the weight of the pancreatic remnant was $40 \%$ of nor mal pancreas. Control mice (shams) underwent laparotomy and mobilization of the pancreas. Body weight, nonfasting blood glucose concentrations, and plasma free fatty acids (FFAs) were measured at between 9 and 11 A.M. on the day of surgery and days 5, 7, 10, 14, 30, 45, and 60 after Px. An intraperitoneal glucose tolerance test (IPGTT) was performed in four control mice, four mice 14 days after $60 \% \mathrm{Px}$, and five mice 60 days after $60 \% \mathrm{Px}$. After overnight fasting, blood samples (20 $\mathrm{\mu l})$ were obtained by tail snip before ( $0 \mathrm{~min}$ ) and 15, 30, 60, and $120 \mathrm{~min}$ after an intraperitoneal injection of glucose $(1 \mathrm{~g} / \mathrm{kg})$. Blood glucose was obtained from the snipped tail and measured with a portable glucose meter (Accutrend GC; Boehringer Mannheim, Mannheim, Germany). FFAs were assayed using a kit from Boehringer Mannheim.

Four groups of mice were studied: 1) Px14 group (mice studied 14 days after $60 \% \mathrm{Px})(n=30)$; 2) Px60 group (mice studied 60 days after $60 \% \mathrm{Px})(n=14)$ 3) control14 group (sham-Px mice of similar body weight to Px14 mice) $(n=12)$; and 4 ) control60 group (sham-Px mice of similar body weight to Px60 mice) $(n=8)$. Islet isolation, cell isolation, and culture. Islets of Langerhans were isolated as previously described (17). Briefly, after pancreas digestion with collagenase (Collagenase A; Boehringer Mannheim) in a stationary bath at $37^{\circ} \mathrm{C}$, islets were separated by centrifugation and hand-picked under a stereomicroscope. Once isolated, islets were dissociated into single cells in a low-calcium medium as previously described (18). Cells were then centrifuged, resuspended in culture medium (RPMI 1640 supplemented with $10 \%$ fetal calf serum, $100 \mathrm{IU} / \mathrm{ml}$ penicillin, $0.1 \mathrm{mg} / \mathrm{ml}$ streptomycin, and $5.6 \mathrm{mmol} / \mathrm{l}$ glucose), and plated on glass coverslips Cells were kept at $37^{\circ} \mathrm{C}$ in a humidified atmosphere of $95 \% \mathrm{O}_{2}, 5 \% \mathrm{CO}_{2}$ and used between $6-10 \mathrm{~h}$ of culture, to avoid reversibility of the changes. When indicated isolated islets were cultured during $48 \mathrm{~h}$ in the same medium and kept at $37^{\circ} \mathrm{C}$ in a humidified atmosphere of $95 \% \mathrm{O}_{2}, 5 \% \mathrm{CO}_{2}$. For intracellular recording experiments, islets were isolated by microdissection as previously described (19).

\section{Electrophysiology}

Patch clamp experiments. Patch pipettes were pulled from Clark Electromedical glass capillaries (Reading, U.K.) using a two-stage puller (Mecanex BB$\mathrm{CH}$, Geneva), with resistances in the range of 3-12 $\mathrm{M} \Omega$ when filled with a standard solution (values in mmol/l): $5 \mathrm{KCl}, 135 \mathrm{NaCl}, 10 \mathrm{HEPES}, 2.5 \mathrm{CaCl}_{2}$, and 1.1 $\mathrm{MgCl}_{2}, \mathrm{pH}$ 7.4. Bath solution contained (in mmol/l) $140 \mathrm{KCl}, 1 \mathrm{CaCl}_{2}, 1 \mathrm{MgCl}_{2}, 10$ HEPES, and 1 EGTA, pH 7.2. Solutions containing ATP (Sigma, St. Louis, MO) were applied through an RSC-100 rapid solution changer (Biologic, Claix, France) $\mathrm{K}_{\text {ATP }}$ channel unitary currents were registered from excised membrane patches in the inside-out configuration (20). Currents were measured using an Axopatch 200 amplifier (Axon Instruments, Foster City, CA) and stored in a tape recorder (DAT, DTR-1202; Biologic) for subsequent analysis with a homemade program. Experiments were replayed through an eight-pole Bessel filter (Frequency Devices, Haverhill, MA) at $1 \mathrm{kHz}$ and sampled at $10 \mathrm{kHz}$. Pipette potential was held at $0 \mathrm{mV}$ throughout the record. The experiments were carried out at room temperature $\left(20-24^{\circ} \mathrm{C}\right)$. Dose-response curves were obtained by integrating the area corresponding to channel activity in the presence of different ATP concentrations $(2.5,5,10,20,40$, and $2,000 \mu \mathrm{mol} / \mathrm{l})$ and fitting these data to the Hill equation. Intracellular recording. Membrane potential of the $\beta$-cell was recorded as described (19). Microdissected islets were fixed with micropins to the bottom of a $50-\mu \mathrm{l}$ chamber and perifused at a rate of $0.8 \mathrm{ml} / \mathrm{min}$ with fresh modified Krebs medium and constantly gassed with a mixture of $\mathrm{O}_{2}(95 \%)$ and $\mathrm{CO}_{2}(5 \%)$ for a final $\mathrm{pH}$ of 7.4. Different glucose concentrations $(0,5.6,11.1,16.7$, and $22.2 \mathrm{mmol} / \mathrm{l})$ were added to the superfusion medium. The test agents reached the chamber with a delay of $3 \mathrm{~s}$. These delays have been corrected for in the figures. Bath temperature was maintained at $36 \pm 1^{\circ} \mathrm{C}$ by a peltier controlled by a thermostat. The temperature of the chamber was continuously monitored with a microthermistor. Recordings were made with an Axoclamp 2B amplifier (Axon Instruments) Data acquisition was performed with Axotape version 2.0 (Axon Instruments) and data analysis with MicroCal Origin version 3.7 (MicroCal Software, Northampton, MA)
$\left[\mathrm{Ca}^{2+}\right]_{\mathrm{i}}$ measurement

Indo-1 loading. Collagenase-isolated islets were incubated for $1 \mathrm{~h}$ at $37^{\circ} \mathrm{C}$ in modified Krebs medium supplemented with $5.6 \mathrm{mmol} / \mathrm{l}$ glucose and $3 \%$ bovine serum albumin. The medium was continuously bubbled with a mixture of $\mathrm{O}_{2}(95 \%)$ and $\mathrm{CO}_{2}(5 \%)$ for a final $\mathrm{pH}$ of 7.4 . Islets were loaded as described (21). Islets were loaded with Indo-1 (Molecular Probes, Eugene, OR) by incubation for $1 \mathrm{~h}$ at room temperature in the described medium with $2 \mu \mathrm{mol} / \mathrm{l}$ of the acetoxymethyl derivative (AM). Indo-1 AM was added as a concentration stock solution in DMSO (Sigma) (final DMSO concentration $0.3 \% \mathrm{vol} / \mathrm{vol}$ ). To facilitate the solubilization of Indo-1/AM in physiologic media, the mixture also contained $10 \%$ (wt/wt) of the nonionic surfactant polyol pluronic F127 (Molecular Probes). After loading, islets were incubated with a modified Krebs medium supplemented with $1 \%$ bovine serum albumin. The Krebs medium was kept at $37^{\circ} \mathrm{C}$ and was constantly gassed with a mixture of $\mathrm{O}_{2}(95 \%)$ and $\mathrm{CO}_{2}(5 \%)$ for a final $\mathrm{pH}$ of 7.4 .

Superfusion of islets. Each islet was then transferred to an open chamber (300 $\mathrm{\mu l}$ volume) mounted on the stage of an epifluorescence Nikon-Diaphot inverted microscope (Nikon, Tokyo). Islets of similar, medium size (100-200 $\mathrm{\mu m}$ diameter) were used for all experiments. Individual islets were left to settle down in the chamber for 1-2 min in the absence of perfusion. Islets usually remained attached to the glass bottom of the chamber during a perfusion experiment. Islets were superfused at a rate of $0.5 \mathrm{ml} / \mathrm{min}$ with fresh modified Krebs medium supplemented with $1 \%$ bovine serum albumin and constantly gassed with a mixture of $\mathrm{O}_{2}(95 \%)$ and $\mathrm{CO}_{2}(5 \%)$ for a final $\mathrm{pH}$ of 7.4. Different glucose concentrations $(3,5.6,11.1$, and $16.7 \mathrm{mmol} / \mathrm{l})$ were added to the superfusion medium. The test agents reached the chamber with a delay of $15 \mathrm{~s}$. These delays have been corrected for in the figures. Bath temperature was maintained at $36 \pm 1{ }^{\circ} \mathrm{C}$ by heating a stainless steel ring controlled by a thermostat. The temperature of the chamber was continuously monitored with a microthermistor.

Measurements of $\left[\boldsymbol{C a}^{2+}\right]_{i} \cdot\left[\mathrm{Ca}^{2+}\right]_{\mathrm{i}}$ was monitored as described (21) by measuring the fluorescence emitted by Indo-1. Indo- 1 was excited at $350 \pm 5 \mathrm{~nm}$ by means of a $100 \mathrm{~W}$ mercury lamp. The level of ultraviolet excitation light compatible with a good signal-to-noise ratio was adjusted by placing neutral-density filters in the light pathway to reduce photobleaching and photodamage of the preparation. The emitted fluorescence was split into two beams with a dichroic mirror $(450 \mathrm{~nm})$, filtered at $410 \pm 5$ and $480 \pm 5 \mathrm{~nm}$, respectively, and detected by two photomultipliers (Thorn EMI 9924B; Middlesex, U.K.). An increase in $\left[\mathrm{Ca}^{2+}\right]_{\mathrm{i}}$ produces a rise in Indo-1 fluorescence at $410 \mathrm{~nm}$; conversely, a fluorescence decrease is observed at $480 \mathrm{~nm}$ (22). The fluorescence ratio $\left(\mathrm{F}_{410} / \mathrm{F}_{480}\right)$ was determined online and filtered at $10 \mathrm{kHz} .\left[\mathrm{Ca}^{2+}\right]_{\mathrm{i}}$ was estimated using the equation proposed by Grynkiewicz et al. (22). Autofluorescence levels were measured from control islets and found to be $<15 \%$ of the total fluorescence.

Insulin measurements. Insulin measurements were performed as described (23). Briefly, collagenase-isolated islets were incubated for $1 \mathrm{~h}$ at $37^{\circ} \mathrm{C}$ in modified Krebs medium supplemented with $5.6 \mathrm{mmol} / \mathrm{l}$ glucose and $3 \%$ bovine serum albumin. The medium was continuously bubbled with a mixture of $\mathrm{O}_{2}(95 \%)$ and $\mathrm{CO}_{2}(5 \%)$ for a final $\mathrm{pH}$ of 7.4. For static incubations, islets were incubated in groups of three in $1 \mathrm{ml}$ fresh modified Krebs buffer with $1 \%$ bovine serum albumin plus the different glucose concentrations $(2.8,4.2,5.6,8.3,11.1,16.7$, and $22.2 \mathrm{mmol} / \mathrm{l})$ for $30 \mathrm{~min}$ at $37^{\circ} \mathrm{C}$. For perifusion experiments, batches of 10 islets were placed in a $50-\mu \mathrm{l} \mathrm{chamber}$ and perifused at a flow rate of $1 \mathrm{ml} / \mathrm{min}$ at $37^{\circ} \mathrm{C}$. The islets were first perifused in $3 \mathrm{mmol} / \mathrm{l}$ glucose for $30 \mathrm{~min}$ to reach a state of stable insulin release. The solutions were prewarmed at $37^{\circ} \mathrm{C}$ and continuously gassed. Throughout the perifusion, effluent was continuously collected at 2-min intervals. The dead time was $2 \mathrm{~min}$ and has been corrected for in the figures. Both static incubation and perifused samples were kept at $-20^{\circ} \mathrm{C}$ until insulin determination. For measurement of insulin content, the medium was removed and islets were washed three times in $1 \mathrm{ml}$ fresh modified Krebs-Ringer bicarbonate buffer (KRBB) supplemented with $2.8 \mathrm{mmol} / \mathrm{l}$ glucose and without BSA. Afterward, islets were sonicated $15 \mathrm{~s} \times 3$ at maximum power (model W-225; Heat Systems-Ultrasonic, Farmingdale, NY) in $100 \mu \mathrm{l}$ of 1:10 acid-ethanol mixture (95\% ethanol, $750 \mathrm{ml}$; concentrated $\mathrm{HCl}, 15 \mathrm{ml} ; \mathrm{H}_{2} \mathrm{O}, 235 \mathrm{ml}$ ). A 50 - $\mu \mathrm{l}$ portion of each sample was kept at $-20^{\circ} \mathrm{C}$ until insulin determination. In addition, aliquots of $15 \mu \mathrm{l}$ of the same samples were stored at $-80^{\circ} \mathrm{C}$ for protein determination. Protein content was measured by Bradford assay. Samples were done in triplicate at each point. Insulin was assayed by radioimmunoassay (RIA) using a kit from DPC (Los Angeles). The RIA included the following steps: addition of anti-porcine insulin guinea pig serum, incubation for $36 \mathrm{~h}$ at $4^{\circ} \mathrm{C}$, addition of freshly labeled $\left[{ }^{125} \mathrm{I}\right]$ (TYR A19)-human insulin, incubation for $18 \mathrm{~h}$ at $4^{\circ} \mathrm{C}$, and precipitation of bound insulin by ethanol. Rat insulin was used to prepare the standard curves. Standard curves and problems were run in triplicate.

$\boldsymbol{\beta}$-Cell mass measurement. Each mouse was anesthetized, and the pancreas (control groups) or pancreatic remnants (Px14 and Px60 groups) were excised, blotted, weighed, fixed in Bouin's solution, and embedded in paraffin. The weight of the pancreatic tissue was determined on a Mettler A240 balance (Metler Instrument, Hightstown, NJ), reading to $0.01 \mathrm{mg}$, as described $(24,25)$. Sections of pancreas were stained with immunoperoxidase for the endocrine non- $\beta$-cells of the islets (15). Immunostaining used a cocktail of antibodies (Dako, Carpinteria, CA): 
TABLE 1

Characteristics of experimental groups

\begin{tabular}{lccc}
\hline Group & Body weight $(\mathrm{g})$ & $\begin{array}{c}\text { Blood glucose } \\
(\mathrm{mmol} / \mathrm{l})\end{array}$ & $\begin{array}{c}\text { Non- } \beta \text {-cell } \\
\text { mass (mg) }\end{array}$ \\
\hline Control14 $(n=5)$ & $33.5 \pm 0.9$ & $6.4 \pm 0.3$ & $1.41 \pm 0.21$ \\
Px14 $(n=6)$ & & $6.4 \pm 0.1$ & $0.25 \pm 0.05$ \\
$\quad$ Day 5 & & $6.2 \pm 0.1$ & \\
Day 7 & & $6.6 \pm 0.2$ & $0.88 \pm 0.18^{*}$ \\
Day 10 & $33.9 \pm 0.9$ & $7.7 \pm 0.2$ & $1.32 \pm 0.15$ \\
Day 14 & $42.9 \pm 1.2$ & $7.1 \pm 0.5$ & $1.67 \pm 0.33$ \\
Px60 $(n=6)$ & $41.4 \pm 0.9$ & $6.7 \pm 0.2$ & $0.12 \pm 0.05^{*}$ \\
Control60 $(n=6)$ & & & $0.15 \pm 0.04^{*}$ \\
\hline
\end{tabular}

Data are means \pm SE. $* P<0.001$ compared with control.

rabbit anti-porcine glucagon (final dilution 1:1,000), rabbit anti-human somatostatin (final dilution 1:1,000), and rabbit anti-human pancreatic polypeptide (final dilution 1:500). A swine anti-rabbit IgG was used as a secondary antibody. $\beta$-Cell mass was measured by point-counting morphometry (25). Each immunoperoxidasestained section was covered systematically using a 48-point grid to obtain the number of intercepts over $\beta$-cells, endocrine non- $\beta$-cells, and other tissue. The $\beta$-cell relative volume was calculated by dividing the intercepts over $\beta$-cells by intercepts over total tissue; then the $\beta$-cell mass was estimated by multiplying $\beta$-cell relative volume by pancreas weight.

MTT assay. Collagenase-isolated islets were incubated for $1 \mathrm{~h}$ at $37^{\circ} \mathrm{C}$ in modified Krebs medium supplemented with $5.6 \mathrm{mmol} / \mathrm{l}$ glucose and $3 \%$ bovine serum albumin. The medium was continuously bubbled with a mixture of $\mathrm{O}_{2}(95 \%)$ and $\mathrm{CO}_{2}$ (5\%) for a final $\mathrm{pH}$ of 7.4. Then, MTT (C,N-diphenyl-N" ${ }^{\prime \prime}-4,5$-dimethyl thiazol 2 yl tetrazolium bromide) reduction was measured as previously described (26). Batches of 15 islets were incubated in $1 \mathrm{ml}$ fresh modified KRBB with $1 \%$ bovine serum albu$\mathrm{min}, 0.5 \mathrm{mg} / \mathrm{ml}$ MTT (Sigma), and the different glucose concentrations (2.8, 4.2, 5.6, $8.3,11.1,16.7$, and $22.2 \mathrm{mmol} / \mathrm{l}$ ) for $30 \mathrm{~min}$ at $37^{\circ} \mathrm{C}$. This incubation time was selected because formazan production had reached a plateau. To solubilize the formazan crystals at the end of the incubation periods, the medium was removed and islets were washed three times in $1 \mathrm{ml}$ fresh modified KRB buffer supplemented with $2.8 \mathrm{mmol} / \mathrm{glucose}$ and without BSA. Afterward, islets were sonicated $15 \mathrm{~s} \times$ 3 at maximum power (model W-225; Heat Systems-Ultrasonic) in $100 \mu \mathrm{l}$ isopropanol. The optical density was recorded with an automatic U-2000 spectrophotometer at $540 \mathrm{~nm}$ (Hitachi, Tokyo). Aliquots $(15 \mu \mathrm{l})$ of islet extracts were stored at $-80^{\circ} \mathrm{C}$ for protein determination. Protein content was measured by Bradford assay. Samples were done in triplicate at each glucose concentration.

Statistical analysis. Patch clamp results were expressed as means \pm SD. For comparisons between two groups, the unpaired Welch's $t$ test (two-tailed) was used. The rest of the results were expressed as means \pm SE. Statistical differences in the dose-response curves were tested using the test of comparison of experimental curves. $P<0.05$ was considered significant.

\section{RESULTS}

Metabolic evolution and $\boldsymbol{\beta}$-cell mass. Normoglycemia and normolipidemia were maintained in all the mice after $60 \%$ Px (Table 1). Postprandial mild hyperglycemia was excluded, because blood glucose was always determined in fed animals. In addition, blood glucose values after IPGTT were similar in mice from control14, Px14, and Px60 groups (Fig. 1).

After $60 \% \mathrm{Px}, \beta$-cell mass increased progressively in Px14 and Px60 groups. Fourteen days after Px, $\beta$-cell mass in the pancreatic remnant was $62.5 \%$ of $\beta$-cell mass in control 14 group, and by day 60 it had increased to $93.6 \%$ of the initial $\beta$-cell mass (control14 group) and $79.0 \%$ of the $\beta$-cell mass in weightmatched controls (control60 group). In contrast, the endocrine non- $\beta$-cell mass increased modestly; on day 60 after Px it was $60 \%$ of the initial non- $\beta$-cell mass (control14) and $53.4 \%$ of weight-matched control (control60 group) (Table 1).

Effect of pancreatectomy on glucose-induced insulin secretion. The glucose-induced insulin secretion from islets in control and Px14 groups is shown in Fig. 2. The relation- ship between insulin secretion and glucose concentration was sigmoidal in both groups; however, the dose-response curve in islets from Px14 group showed a significant displacement to the left in the dose response $\left(\mathrm{EC}_{50}=7.46 \pm\right.$ $0.27 \mathrm{mmol} / \mathrm{l})$ when compared with islets from control14 group $\left(\mathrm{EC}_{50}=10.24 \pm 0.08 \mathrm{mmol} / \mathrm{l}\right)\left(F_{(2,56)}=11.76 ; P<0.001\right)$. A broader glucose response range and a reduced glucose threshold for insulin secretion were seen in Px14 (Fig. 2A). Islets from Px14, when compared with the control14 group, showed increased insulin secretion in response to lower glucose concentrations (5.6 and $8.3 \mathrm{mmol} / \mathrm{l}$ glucose, respectively). Islets from Px14 group recovered a normal glucoseinduced insulin secretion after 48-h culture in $5.6 \mathrm{mmol} / \mathrm{g} \mathrm{glu}-$ cose (Fig. 2A). In addition, at any glucose concentration $>5.6$ $\mathrm{mmol} / \mathrm{l}$, islets from the Px14 group showed a higher insulin release than control14 group islets $(P<0.001)$ (Fig. $2 A)$. Insulin content in islets from control14, Px14, and $48 \mathrm{~h}-\mathrm{cul}-$ tured Px14 groups were similar $(19.09 \pm 1.56,17.76 \pm 1.25$, and $20.31 \pm 2.29 \mathrm{ng} / \mathrm{\mu g}$ protein, respectively; 15 islets from 4 mice in control14 and Px14 groups and 8 islets from 3 mice in $48 \mathrm{~h}-$ cultured Px14 group). Finally, protein content in islets from control14 and Px14 groups was also similar $(2.72 \pm 0.19$ and $2.99 \pm 0.34 \mu \mathrm{g}$ protein/islet, respectively; 15 islets from 4 mice in both groups).

Perfused mouse islets responded to a stepwise increase in glucose concentration with a rapid and transient burst of insulin secretion (first phase) followed by a plateau (second

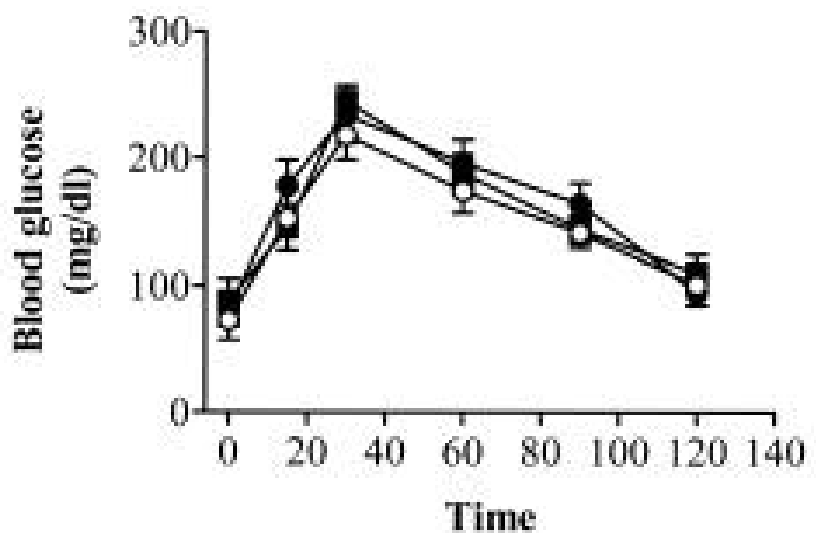

FIG. 1. Effect of pancreatectomy on glucose tolerance in control14 $(\bigcirc)$ $(n=4), \operatorname{Px14}(O)(n=4)$, and Px60 ( $(n)(n=5)$ groups. Results are expressed as means \pm SE. 

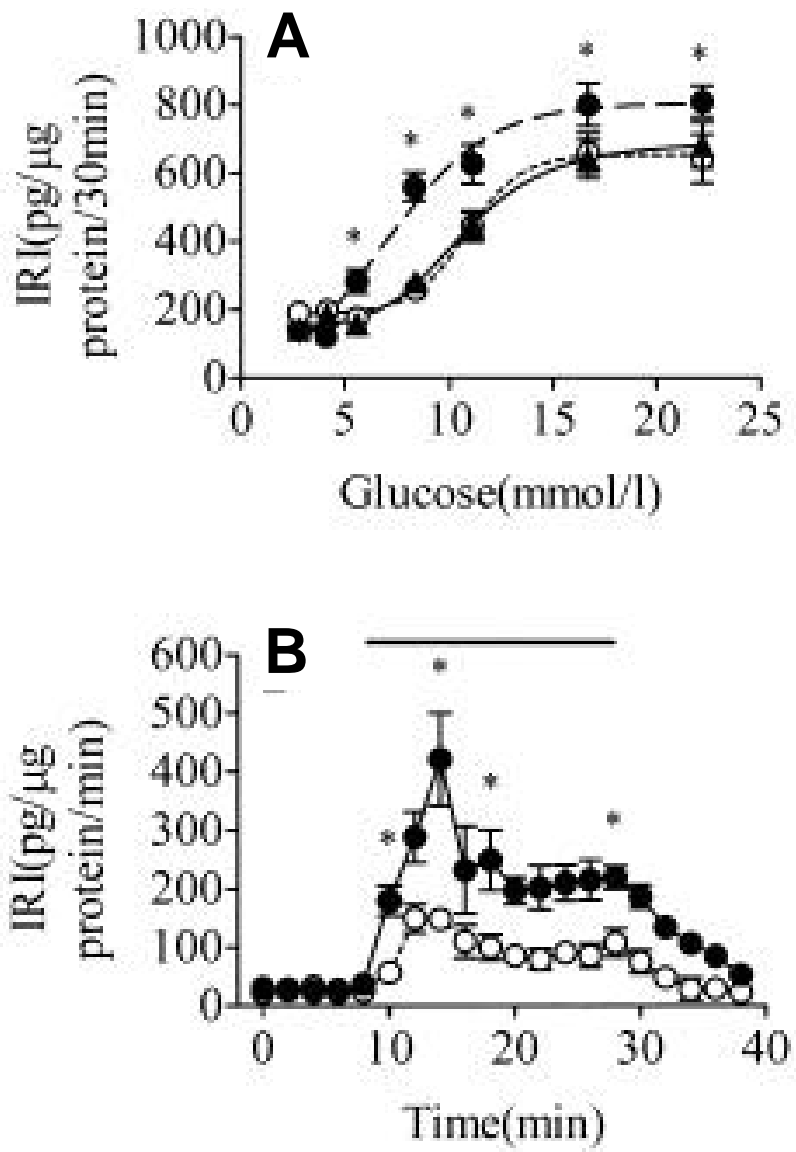

FIG. 2. Effect of pancreatectomy on glucose-induced insulin secretion. $A$ : Islets from control14 ( $\bigcirc), P x 14(\bullet)$, and Px14 cultured $48 \mathrm{~h}$ in $5.6 \mathrm{mmol} / \mathrm{l}$ glucose $(\Delta)$ groups were incubated in batches of three for $30 \mathrm{~min}$ at $37^{\circ} \mathrm{C}$ in $1 \mathrm{ml}$ fresh modified KRBB with $1 \%$ bovine serum albumin plus different glucose concentrations. Values are expressed as means $\pm S E$ of eight experiments. $* P<0.05$ compared with control group. B: Batches of 10 islets from control14 (O) and Px14 (O) groups were perfused at a flow rate of $1 \mathrm{ml} / \mathrm{min}$ at $37^{\circ} \mathrm{C}$. After a 30-min stabilization with $3 \mathrm{mmol} / \mathrm{l}$ glucose, the islets were perfused for $10 \mathrm{~min}$ with $3 \mathrm{mmol} / \mathrm{l}$ glucose, then for $20 \mathrm{~min}$ with $22 \mathrm{mmol} / \mathrm{l}$ glucose (as indicated by the bar), and finally for $10 \mathrm{~min}$ with $3 \mathrm{mmol} / \mathrm{l}$ glucose. The perfusion medium was fresh modified KRBB with $1 \%$ bovine serum albumin alone. Insulin was assayed by RIA, and determinations were run in triplicate. Values are expressed as means $\pm \mathrm{SE}$ of six experiments. $* P<0.001$ compared with control14 group.

phase) which lasted as long as glucose was present. Insulin release from Px14 islets increased significantly $(P<0.001)$ compared with control14 group islets (Fig. $2 B$ ).

Effect of pancreatectomy on membrane potential and $\left[\mathrm{Ca}^{2+}\right]_{\mathbf{i}}$. The glucose-induced electrical activity in $\beta$-cells from control14 and Px14 islets is summarized in Fig. 3. In the Px14 group, $\beta$-cells ( 8 from 8 islets in 6 mice) showed an increased glucose sensitivity (Fig. $3 B$ ) compared with $\beta$-cells from control14 group islets (Fig. $3 A$ ) ( $7 \beta$-cells from 7 islets in 4 mice). $\beta$-Cells from the Px14 group showed oscillatory electrical activity at glucose concentrations $(5.6 \mathrm{mmol} / \mathrm{l})$ (Fig. $3 B$ ) lower than in $\beta$-cells from the control14 group $(11.1 \mathrm{mmol} / \mathrm{l})$ (Fig. $3 A)$. Furthermore, the pattern of response in control14 group $\beta$-cells elicited with maximal glucose concentrations (22 mmol/l) (data not shown) was achieved in $\beta$-cells from the Px14 group with $16.7 \mathrm{mmol} / \mathrm{glucose}$ (Fig. $3 B$ ). In contrast, no significant differences were found in the electrical activity of $\beta$-cells from control and Px60 groups
A

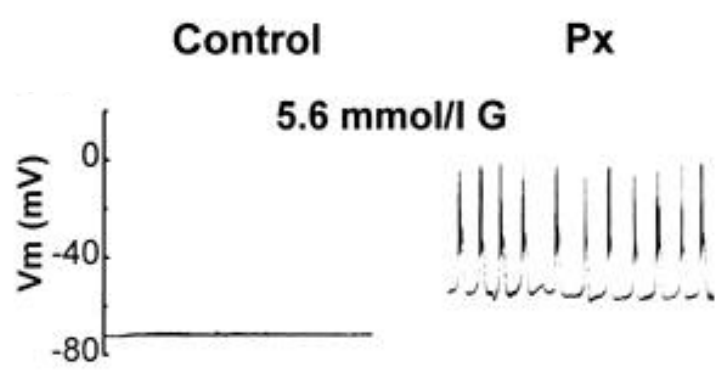

$11.1 \mathrm{mmol} / \mathrm{l} \mathrm{G}$

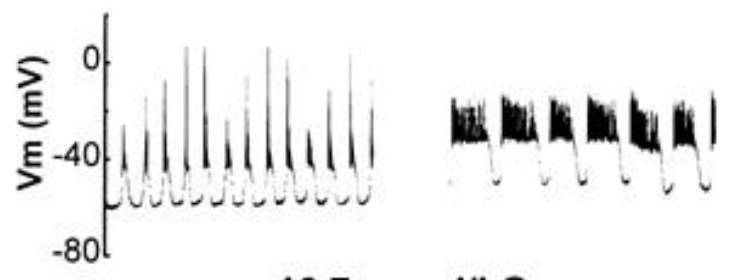

$16.7 \mathrm{mmol} / \mathrm{l} \mathrm{G}$

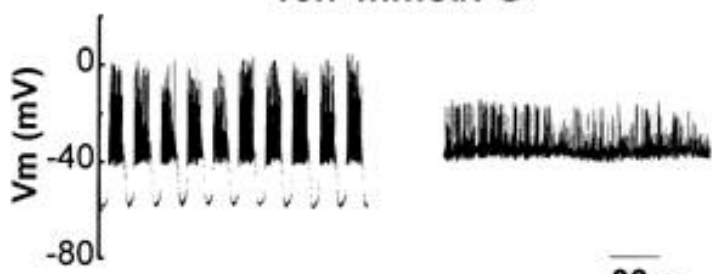

$\overline{30 s}$
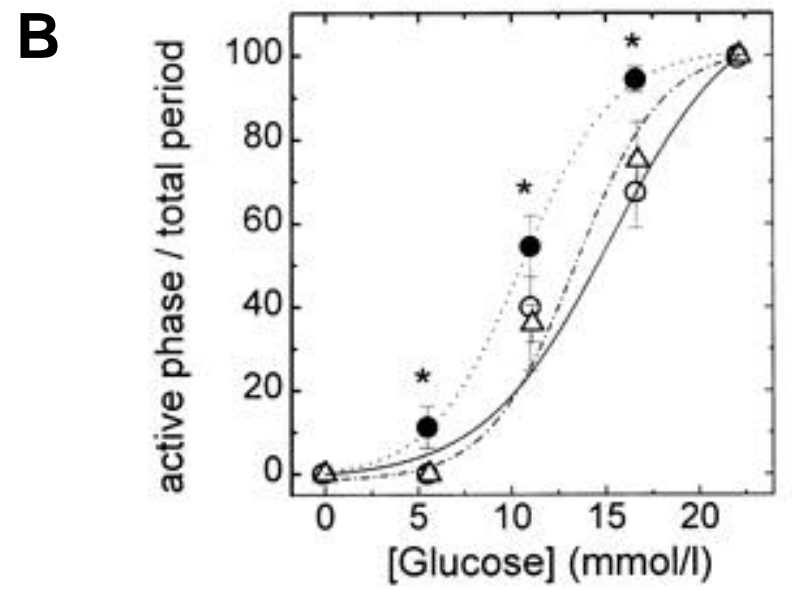

FIG. 3. Glucose-induced electrical activity in islets from pancreatectomized mice. $A$ : Representative examples of the effects of different glucose concentrations $(5.6,11.1$, and $16.7 \mathrm{mmol} / \mathrm{l})$ on intracellularly recorded membrane potential of a pancreatic $\beta$-cell in the intact islet. $B$ : Fraction of time in the active phase in control14 $(\bigcirc), \operatorname{Px14}(\bullet)$, and Px60 $(\triangle)$ islet $\beta$-cells. In control14, Px14, and Px60 groups, the same islet was perfused with different glucose concentrations. G, glucose. $* P<0.05$ compared with control14 group.

(12 $\beta$-cells from 12 islets in 4 mice) (data not shown). When the parameters studied (fraction of time in active phase) were plotted as a function of glucose concentrations, the dose-response curve in $\beta$-cells from Px14 group was found to be shifted left compared with $\beta$-cells from control14 and Px60 groups (Fig. $3 B$ ). Values for the input resistance in $\beta$-cells from control14 and Px14 groups were similar under non- 
A

\section{Control}

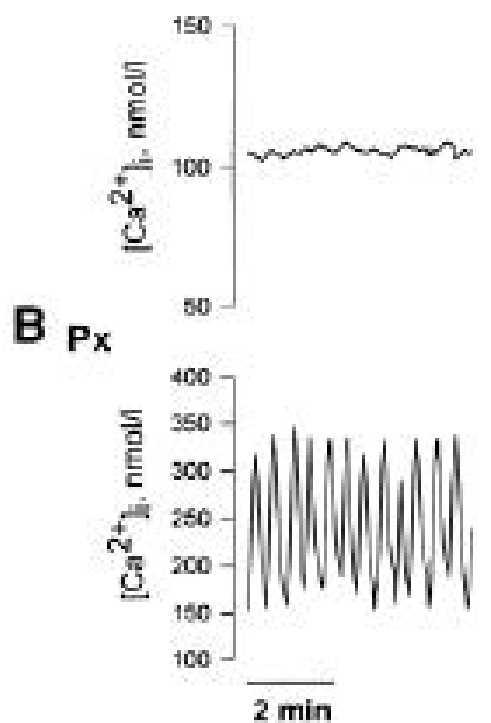

$11.1 \mathrm{mmoll} \mathrm{G}$
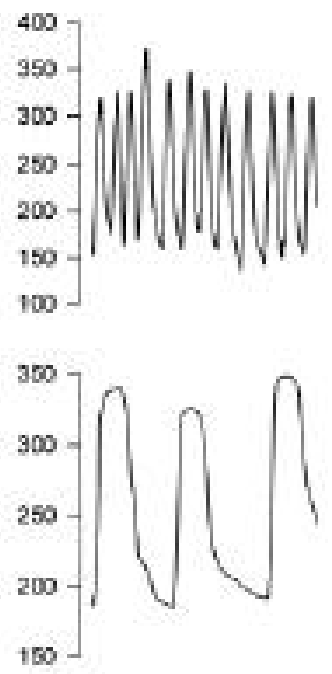

stimulatory (180 \pm 30 and $150 \pm 20 \mathrm{M} \Omega$, respectively) and stimulatory ( $235 \pm 35$ and $220 \pm 35 \mathrm{M} \Omega$, respectively) glucose concentrations.

$\left[\mathrm{Ca}^{2+}\right]_{\mathrm{i}}$ responses to glucose are shown in Fig. 4. Islets from the Px14 group showed $\left[\mathrm{Ca}^{2+}\right]_{\mathrm{i}}$ oscillations in response to lower glucose concentrations $(5.6 \mathrm{mmol} / \mathrm{l})$ (Fig. $4 B$ ) than control14 group islets $(11.1 \mathrm{mmol} / \mathrm{l})$ (Fig. $4 A)$. In the presence of $11.1 \mathrm{mmol} / \mathrm{l}$ glucose, $\left[\mathrm{Ca}^{2+}\right]_{\mathrm{i}}$ oscillations in $\mathrm{Px} 14$ group were broader in duration $(121.1 \pm 10.3 \mathrm{~s}, P<0.001 ; 12$ islets from 5 mice) (Fig. $4 B$ ) compared with islets from the control14 group ( $20.7 \pm 1.7 \mathrm{~s} ; 17$ islets from 5 mice) (Fig. $4 A$ ). In addition, the pattern of response in islets from control 14 group elicited with maximal glucose concentrations (22 mmol/l) (data not shown) was achieved in Px14 islets with $16.7 \mathrm{mmol} / \mathrm{lglu}$ cose (Fig. $4 B$ ). In contrast, no significant differences were found in $\left[\mathrm{Ca}^{2+}\right]_{i}$ in islets from the Px60 group (7 islets from 4 mice) compared with islets from the control14 group (data not shown).

Islets from the Px14 group recovered their normal glucoseinduced $\left[\mathrm{Ca}^{2+}\right]_{\mathrm{i}}$ oscillatory pattern after 48-h culture (Fig. 5). As in islets from the control14 group, $48 \mathrm{~h}$-cultured Px14 islets did not exhibit any $\left[\mathrm{Ca}^{2+}\right]_{\mathrm{i}}$ oscillatory behavior in response to $5.6 \mathrm{mmol} / \mathrm{l}$ glucose (12 islets from 3 mice) (Fig. $5 B$ ) and elicited $11.1 \mathrm{mmol} / \mathrm{l}$ glucose-induced regular $\left[\mathrm{Ca}^{2+}\right]_{\mathrm{i}}$ oscillations (Fig. 5C). Of note, 48-h culture in $5.6 \mathrm{mmol} / \mathrm{l}$ glucose did not significantly affect glucose-induced insulin release in control islets (data not shown). There were no significant differences between the $\left[\mathrm{Ca}^{2+}\right]_{\mathrm{i}}$ levels $(10 \mathrm{~min}$ of register): $339.8 \pm 31.3 \mathrm{nmol} / \mathrm{l}$ in control14 group islets perfused with $11.1 \mathrm{mmol} / \mathrm{l}$ glucose (Fig. $4 A$ ); $367.5 \pm 41.3 \mathrm{nmol} / \mathrm{l}$ in Px14 group islets perfused with $5.6 \mathrm{mmol} / \mathrm{l}$ glucose (Fig. $4 B$ ); $379.4 \pm$ $52.8 \mathrm{nmol} / \mathrm{l}$ in Px14 group islets perfused with $5.6 \mathrm{mmol} / \mathrm{l} \mathrm{glu}$ cose (Fig. $5 A$ ); and $402.7 \pm 49.6 \mathrm{nmol} / \mathrm{l}$ in $48 \mathrm{~h}$-cultured Px14 group islets perfused with $11.1 \mathrm{mmol} / 1$ glucose (Fig. $5 C$ ).

Effect of pancreatectomy on $K_{\text {ATP }}$ channel activity. Figure 6 shows the dose-response relationship for the inhibition of $\mathrm{K}_{\text {АтP }}$ channel activity in the presence of different concentrations of ATP in $\beta$-cells from Px14 and control14 groups. The two representative current records (control

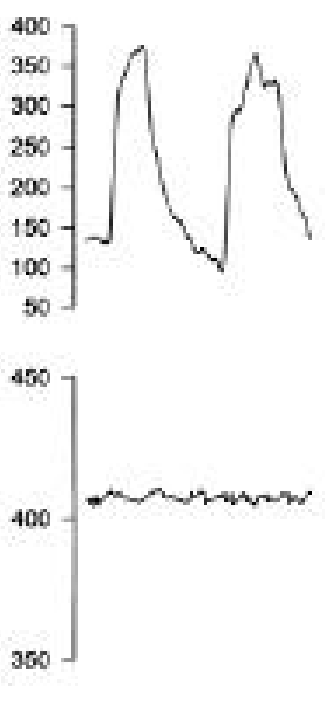

FIG. 4. Glucose-induced $\left[\mathrm{Ca}^{2+}\right]_{i}$ changes in islets from pancreatectomized mice. Representative examples of the effect of different glucose concentrations $(5.6,11.1$, and $16.7 \mathrm{mmol} / \mathrm{l})$ on $\left[\mathrm{Ca}^{2+}\right]_{\mathrm{i}}$. In control14 and Px14 groups, the same islet was perfused with different glucose concentrations. G, glucose.

and Px14) shown at the top illustrate the effects of 2.5 and $40 \mu \mathrm{mol} / \mathrm{A}$ ATP on $\mathrm{K}_{\mathrm{ATP}}$ channel activity. Patches were initially exposed to $2 \mathrm{mmol} / \mathrm{l} \mathrm{ATP}$, then to $0 \mathrm{mmol} / \mathrm{l} \mathrm{ATP}$, then to a test ATP concentration. ATP (2 mmol/l) was applied after every test to minimize rundown. The current in $2 \mathrm{mmol} / \mathrm{l}$ ATP was

A
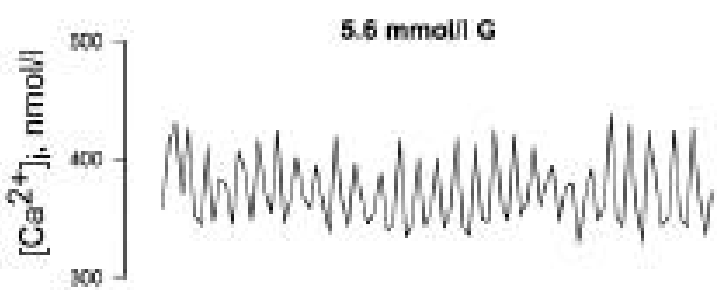

B

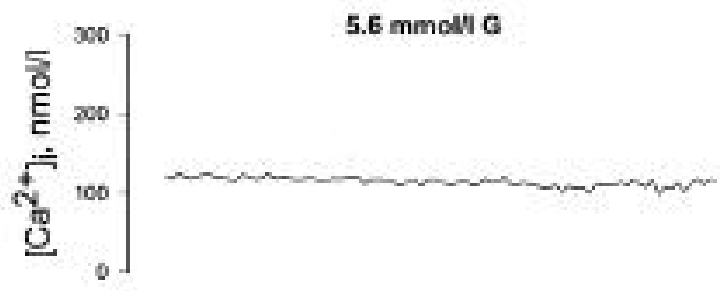

C

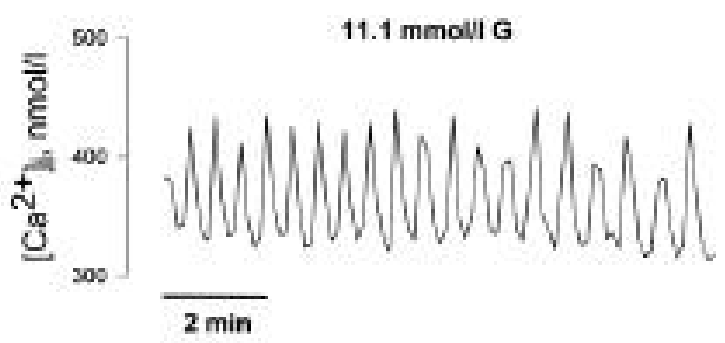

FIG. 5. Recovery of glucose-induced $\left[\mathrm{Ca}^{2+}\right]_{\mathrm{i}}$ changes in islets from pancreatectomized mice. $A$ : Representative example of the effect of $5.6 \mathrm{mmol} / \mathrm{l}$ glucose concentration on $\left[\mathrm{Ca}^{2+}\right]_{i}$ in freshly isolated islets from Px14 group. B: Representative example of the effect of $5.6 \mathrm{mmol} / \mathrm{l}$ glucose concentration on $\left[\mathrm{Ca}^{2+}\right]_{\mathrm{i}}$ in $48 \mathrm{~h}$-cultured islets from Px14 group. $C$ : Representative example of the effect of $11.1 \mathrm{mmol} / \mathrm{g}$ glucose concentration on $\left[\mathrm{Ca}^{2+}\right]_{i}$ in $48 \mathrm{~h}$-cultured islets from Px14 group. Groups are described in METHODs. G, glucose. 
A

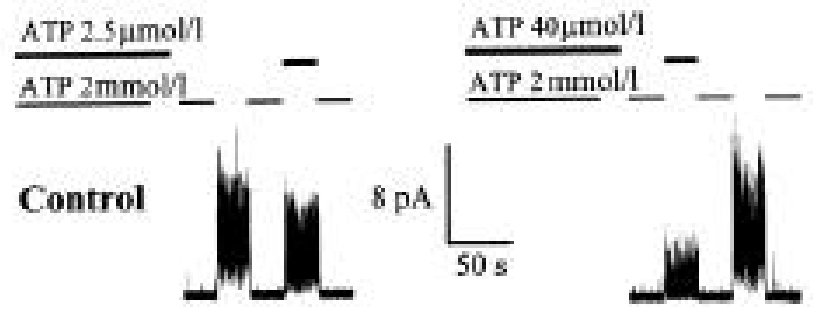

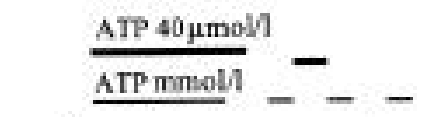
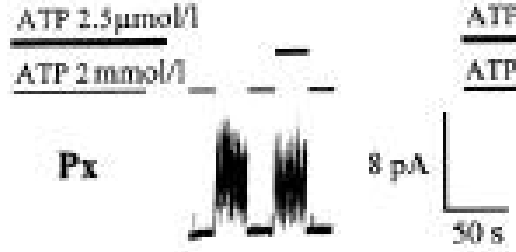

B

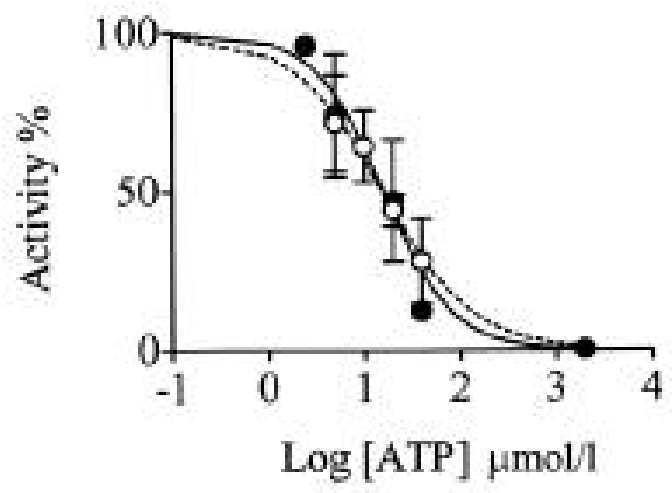

FIG. 6. Effects of ATP on $\mathrm{K}^{+}{ }_{\text {ATP }}$ channel activity in inside-out membrane patches from pancreatic $\beta$-cells. $A$ : Representative recordings of channel activity in a patch exposed to 2.5 and $40 \mathrm{\mu mol} / \mathrm{l}$ ATP, as indicated above the record, in control14 and Px14 groups. $B$ : Dose-response relationship for ATP inhibition of $K_{\mathrm{ATP}}$ channel activity in pancreatic $\beta$-cells from control14 $(\bigcirc)$ and Px14 (O) groups. In this figure, the ordinate represents patch current relative to that in $0 \mathrm{mmol} / \mathrm{l}$ ATP $\left(I_{\max }\right)$. The points show means $\pm \mathrm{SD}, n=3$. Groups are described in METHODS.

taken as $\emptyset$ current and subtracted from the current measured in each test solution. Current in the absence of ATP was taken as $I_{\max }$. The average current in each ATP exposure was expressed as a fraction of $I_{\max }$. No significant differences for ATP inhibition were found between $\beta$-cells from the Px14 and controll4 groups. The data could be fitted to a Hill equation with an $\mathrm{IC}_{50}$ of $15.9 \mathrm{\mu mol} / \mathrm{l}$ and a Hill coefficient of 1.2 for the Px14 group $(n=3)$ and $\mathrm{an}_{50}$ of $15.5 \mu \mathrm{mol} / \mathrm{l}$ and a Hill coefficient of 0.9 for the control14 group $(n=3)$ (Fig. $6 B$ ). No significant difference was observed in the unitary current between $\beta$-cells from Px14 and control14 groups (data not shown).

MTT reduction. Both control14 and Px14 islets incubated in the presence of MTT showed a sigmoidal increase in formazan production as a function of increasing extracellular glucose concentration, reaching a maximal value at $11.1 \mathrm{mmol} / \mathrm{l}$ glucose (Fig. 7). However, a significant displacement to the left in the dose-response curve was observed in Px14 islets $\left(\mathrm{EC}_{50}=7.14 \pm 0.12 \mathrm{mmol} / \mathrm{l}\right)$ compared with control14 group islets $\left(\mathrm{EC}_{50}=9.76 \pm 0.25 \mathrm{mmol} / \mathrm{l}\right)\left(F_{(2,50)}=13.41 ; P<0.001\right)$ (Fig. 7). Additionally, there was a broadening in the glucose response range through a reduction of the threshold to glucose metabolism. Compared with basal values, MTT reduc-

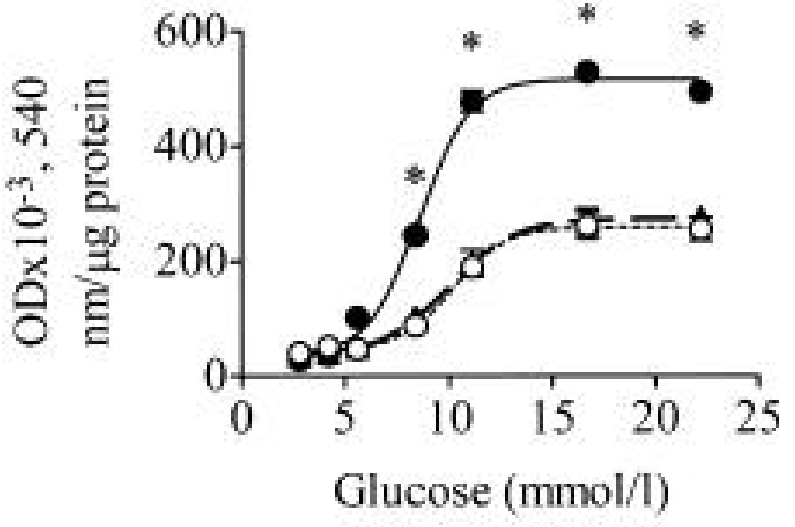

FIG. 7. Effect of pancreatectomy on glucose-induced MTT reduction. Batches of 15 islets from control14 (๑), Px14 (๑), and Px14 cultured for $48 \mathrm{~h}$ in $5.6 \mathrm{mmol} / \mathrm{l}$ glucose $(\Delta)$ groups were incubated for $30 \mathrm{~min}$ at $37^{\circ} \mathrm{C}$ in $1 \mathrm{ml}$ fresh modified $\mathrm{KRB}$ buffer with $1 \%$ bovine serum albu$\min , 0.5 \mathrm{mg} / \mathrm{ml}$ MTT, and different glucose concentrations. The formation of intracellular MTT-formazan crystals was measured by spectrophotometry at $540 \mathrm{~nm}$. All determinations were run in triplicate. Values are expressed as means $\pm \mathrm{SE}$ of four experiments. $* P<0.001$ compared with control14 group.

tion in Px14 islets was increased at $5.6 \mathrm{mmol} / \mathrm{l}$ glucose $(P<$ 0.01) (Fig. 7); in control14 group islets, the increase appeared at $8.3 \mathrm{mmol} / \mathrm{l}$ glucose $(P<0.05)$ (Fig. 7$)$. Moreover, Px14 islets showed a significant increase in MTT glucose reduction at glucose concentrations higher than $5.6 \mathrm{mmol} / \mathrm{l}(P<0.01)$, and the maximal values were twice those observed in islets from control14 group. Islets from Px14 group recovered a normal MTT glucose reduction after 48-h culture in $5.6 \mathrm{mmol} / \mathrm{l}$ glucose (Fig. 7).

\section{DISCUSSION}

In this study, we investigated the stimulus-secretion coupling mechanisms in $60 \%$ Px mice, a model in which normoglycemia and normolipidemia are maintained despite reduced $\beta$-cell mass.

The metabolic characteristics and growth of the pancreatic remnant in $60 \% \mathrm{Px}$ rats have been well characterized (16), and we anticipated that the model would have similar characteristics in mice. The $60 \% \mathrm{Px}$ mice remained normoglycemic despite the significant $\beta$-cell mass reduction, excluding the possibility of any transitory hyperglycemia interfering with changes in glucose sensitivity. In addition, $60 \% \mathrm{Px}$ mice were normolipidemic, excluding the possibility that altered plasma FFA levels led to the observed changes. Furthermore, progressive $\beta$-cell regeneration in the pancreatic remnant provided an excellent model to investigate the reversibility of changes in $\beta$-cell glucose sensitivity and their relationship with $\beta$-cell mass. Although $\beta$-cell mass increased markedly after partial Px, it was still reduced 14 days after Px, at which time $\beta$-cell glucose sensitivity (insulin secretion, electrical activity, and $\left[\mathrm{Ca}^{2+}\right]_{i}$ ) was increased. In contrast, 60 days after Px, $\beta$-cell mass increased to $79 \%$ of control values and glucose sensitivity was similar in control and Px60 mice. We suggest that the increased glucose sensitivity 14 days after Px was an adaptive response of $\beta$-cells to meet the increased metabolic demand placed on a reduced $\beta$-cell mass. The reversibility of this adaptive mechanism, shown by the normal glucose sensitivity of the Px 60 group, was confirmed by the normal glucose sensitivity observed in Px 14 groups islets after a 48-h culture period. 
Increased $\beta$-cell sensitivity to glucose has been shown to precede the loss of glucose-induced insulin secretion in diabetic rats and could be the event initiating impaired glucose potentiation elicited by chronic hyperglycemia (8). However, glucose supersensitivity has also been found in several normoglycemic conditions characterized by the increased workload placed on $\beta$-cells. This suggests that hyperglycemia is not the cause of increased $\beta$-cell sensitivity. Changes have been found in glucokinase, hexokinase, and GLUT2 as islets adapt to increased metabolic demand, but may not fully account for the increased glucose sensitivity (27). Recently, we described an increased $\beta$-cell glucose sensitivity in islet cells transplanted into diabetic mice that maintained normoglycemia with a reduced cell $\beta$-mass (15). The glucose-induced electrical activity and $\left[\mathrm{Ca}^{2+}\right]_{\mathrm{i}}$ response in transplanted $\beta$-cells was found to be similar to that found in Px14 $\beta$-cells. In that study, glucose supersensitivity was attributed to a resting decrease in the fraction of blockable $\mathrm{K}_{\mathrm{ATP}}$ channels, which could be caused by either an increase in the glucose metabolic modulators of $\mathrm{K}_{\mathrm{ATP}}$ channels or a change in the properties of the channel. To address the second possibility, we studied the input resistance and $K_{\text {ATP }}$ channel sensitivity to ATP. No significant differences were observed in the input resistances between $\beta$-cells from Px14 and control groups, indicating that the numbers of $\mathrm{K}_{\mathrm{ATP}}$ channels were similar for $\beta$-cells from both groups. Finally, patch-clamp studies did not show any modification of ATP effect on $\mathrm{K}_{\mathrm{ATP}}$ channels in $\beta$-cells from Px14 mice compared with control mice. Furthermore, Px did not affect the magnitude of the unitary current. These data, together with no significant modification in channel activity, imply that there is no significant change in the open probability.

Glucose metabolism was assessed by the MTT reduction test. The intracellular reduction of the tetrazolium dye MTT allows determination of $\beta$-cell metabolic activity (26). A very good correlation has been shown between MTT reduction, glycolytic flux, glucose oxidation, and insulin secretion in INS cells and rat islets (26). The MTT reduction experiments showed a significant displacement to the left of the $\beta$-cell oxidative metabolism, with an increased glucose metabolization at all glucose concentrations tested (except $2.8 \mathrm{mmol} / \mathrm{l}$ glucose) in islets from the Px14 group. A similar pattern was observed for insulin release in islets from the Px14 group. These data suggest that metabolic steps of the stimulussecretion coupling mechanism are probably responsible for the increased glucose sensitivity. An additional role of glucokinase in this phenomenon cannot be ruled out (12). The enhanced insulin secretion observed in Px14 islets from $5.6 \mathrm{mmol} / \mathrm{l}$ glucose could also be indicative of augmentation of the $\mathrm{Ca}^{2+}$ dependent mechanism of insulin secretion by $\mathrm{K}_{\mathrm{ATP}}$ channel-independent glucose signaling. In addition, GTP-dependent mechanisms (28) could be involved in the increased glucose-induced insulin secretion elicited by Px islets.

The results described here show that in $\beta$-cells from the Px14 group, 1) there is a displacement to the left of the glucose dose-response curve and $\beta$-cell oxidative metabolism, with a decrease in the glucose threshold; 2) there is an increase in the dynamic range of the system in terms of oscillatory electrical activity and $\left[\mathrm{Ca}^{2+}\right]_{\mathrm{i}}$ oscillations; and 3) there are no modifications in the channel properties of the $\mathrm{K}_{\mathrm{ATP}}$ channel. In summary, we have found an increased sensitivity to glucose for insulin secretion 14 days after $60 \% \mathrm{Px}$, during which time normoglycemia was maintained with a reduced $\beta$-cell mass. $\beta$-Cell glucose sensitivity returned to normal when $\beta$-cell mass increased to control mice values, indicating that the change in sensibility was a reversible adaptive mechanism in response to the increased workload placed on $\beta$-cells. The lowered glucose set-point was not due to modification of the $\mathrm{K}_{\mathrm{ATP}}$ channel's intrinsic properties. Thus, the results suggest that increased glucose sensitivity in terms of insulin secretion, electrical activity, and $\mathrm{Ca}^{2+}$ signaling is probably due to changes in glucose metabolism.

\section{ACKNOWLEDGMENTS}

This work was partially supported by grants FIS 94/0014-01 (B.S.), FIS 96/1994-01 (B.S.), and FIS 96/2012 (J.V.S.-A.) from Fondo de Investigaciones Sanitarias de la Seguridad Social and by grant SAF 97-0118 (E.M.) from Comisión Interministerial de Ciencia y Tecnologia. J.M.R. is a recipient of a research studentship from Generalitat Valenciana. E.A. was supported by a Formación Personal Investigador Doctoral Fellowship of the Dirección General de Investigación Científica y Técnica. M.R. was the recipient of a fellowship from Fundació August Pi i Sunyer.

We thank Dr. E. Roche for helpful discussion and good advice. We thank N. Illera, A. Perez, R. García, and O. Aranda for skilled technical assistance.

\section{REFERENCES}

1. Efrat S, Tal M, Lodish HF: The pancreatic $\beta$-cell glucose sensor. TIBS 19:535-538, 1994

2. Matchinsky FM: Glucokinase as glucose sensor and metabolic signal generator in pancreatic $\beta$-cells and hepatocytes. Diabetes 39:647-652, 1990

3. Ashcroft FM, Harrison D, Ashcroft SJH: Glucose induced closure of single potassium channels in isolated rat pancreatic $\beta$-cells. Nature 312:446-448, 1984

4. Henquin JC, Meissner HP: Significance of ionic fluxes and changes in membrane potential for stimulus-secretion coupling in pancreatic $\beta$-cells. Experientia 40:1043-1052, 1984

5. Valdeolmillos M, Santos RM, Contreras D, Soria B, Rosario LM: Glucoseinduced oscillations of intracellular $\mathrm{Ca}^{2+}$ concentration resembling bursting electrical activity in single mouse islets of Langerhans. FEBS Lett 259:19-23, 1989

6. Martin F, Sanchez-Andres JV, Soria B: Slow $\left[\mathrm{Ca}^{2+}\right]_{\mathrm{i}}$ oscillations induced by ketoisocaproate in single mouse pancreatic islets. Diabetes 44:300-305, 1995

7. Leahy JL: Natural history of $\beta$-cell dysfunction in NIDDM. Diabetes Care 13:992-1010, 1990

8. Leahy JL, Bumbalo LM, Chen C: Beta-cell hypersensitivity for glucose precedes loss of glucose-induced insulin secretion in $90 \%$ pancreatectomized rats. Diabetologia 36:1238-1244, 1993

9. Chen C, Hosokawa H, Bumbalo LM, Leahy JL: Mechanism of compensatory hyperinsulinemia in normoglycemic insulin-resistant spontaneously hypertensive rats: augmented enzymatic activity of glucokinase in $\beta$-cells. $J$ Clin Invest 94:399-404, 1994

10. Timmers KL, Powell AM, Voyles NR, Solomon D, Wilkins SD, Bhathena S, Recant L: Multiple alterations in insulin responses to glucose in islets from 48-h glucose-infused nondiabetic rats. Diabetes 39:1436-1444, 1990

11. Parsons JA, Brelje TC, Sorenson RL: Adaptation of islets of Langerhans to pregnancy: increased islet cell proliferation and insulin secretion correlates with the onset of placental lactogen secretion. Endocrinology 130:1459-1466, 1992

12. Leahy JL: $\beta$-Cell dysfunction with chronic hyperglycemia: the "overworked $\beta$-cell" hypothesis. Diabetes Rev 4:298-319, 1996

13. Rabuazzo AM, Patanè G, Anello M, Piro S, Vigheri R, Purrello F: Hexokinase shift to mitochondria is associated with an increased sensitivity to glucose in rat pancreatic islets. Diabetes 46:1148-1152, 1997

14. Unger RH: Diabetic hyperglycemia: link to impaired glucose transport in pancreatic $\beta$-cells. Science 251:1200-1025, 1991

15. Soria B, Martin F, Andreu E, Sanchez-Andres JV, Nacher V, Montana E: Diminished fraction of blockade ATP-sensitive $\mathrm{K}^{+}$channels in islets transplanted into diabetic mice. Diabetes 45:1755-1760, 1996

16. Leahy JL, Bonner-Weir S, Weir GC: Minimal chronic hyperglycemia is a critical determinant of impaired insulin secretion after an incomplete pancreatectomy. J Clin Invest 81:1407-1414, 1988

17. Lernmark Å: The preparation of, and studies on, free cell suspensions from 
mouse pancreatic islets. Diabetologia 10:431-438, 1974

18. Ripoll C, Martin F, Rovira JM, Pintor J, Miras-Portugal MT, Soria B: Diadenosine polyphosphates: a novel class of glucose-induced intracellular messengers in the pancreatic $\beta$-cell. Diabetes 45:1431-1434, 1996

19. Sanchez-Andres JV, Soria B: Muscarinic inhibition of the pancreatic $\beta$-cell. Eur J Pharmacol 205:89-91, 1991

20. Hamill OP, Marty A, Neher E, Sakmann B, Sigworth FJ: Improved patchclamp techniques for high-resolution current recordings from cells and cell-free membrane patches. Pflügers Archiv 391:85-100, 1981

21. Valdeolmillos M, Santos RM, Contreras D, Soria B, Rosario LM: Glucoseinduced oscillations of intracellular $\mathrm{Ca}^{2+}$ concentration resembling bursting electrical activity in single pancreatic islets. Pflügers Archiv 418:417-422, 1989

22. Grynkiewicz G, Poenie M, Tsien RY: A new generation of $\mathrm{Ca}^{2+}$ indicators with greatly improved fluorescence properties. J Biol Chem 260:3440-3450, 1985

23. Bolea S, Pertusa JAG, Martin F, Sanchez-Andres JV, Soria B: Regulation of pan- creatic $\beta$-cell electrical activity and insulin release by physiological amino acid concentrations. Pflügers Archiv 433:699-704, 1997

24. Montana E, Bonner-Weir S, Weir GC: Transplanted beta cell response to increased metabolic demand: changes in beta cell replication mass. J Clin Invest 93:1577-1582, 1994

25. Weibel ER: Point counting methods. In Sterological Methods. Vol. 1. London, Academic Press, 1979, p. 101-161

26. Janjic D, Wollheim CB: Islet cell metabolism is reflected by the MTT (tetrazolium) colorimetric assay. Diabetologia 35:482-485, 1992

27. Wheinhaus AJ, Stout LE, Sorenson RL: Glucokinase, hexokinase, glucose transporter 2 and glucose metabolism in islets during pregnancy and prolactintreated islets in vitro: mechanisms for long term up-regulation of islets. Endocrinology 137:1640-1649, 1996

28. Meredith M, Rabaglia ME, Metz JA: Evidence of a role for GTP in the potentiation of $\mathrm{Ca}^{2+}$-induced insulin secretion by glucose in intact rat islets. J Clin Invest 96:811-821, 1995 